Online: http://journal.uny.ac.id/index.php/jppfa

\title{
REVITALISASI NILAI-NILAI BHINNEKA TUNGGAL IKA DAN KEARIFAN LOKAL BERBASIS LEARNING SOCIETY PASCAKONFLIK SOSIAL DI TERNATE
}

Umar M. Sadjim $^{1)}$, Noeng Muhadjir ${ }^{2)}$, FX.Sudarsono ${ }^{3)}$

Universitas Muhammadiyah Maluku Utara, Universitas Negeri Yogyakarta ${ }^{23)}$ gupojosa@yahoo.co.id; Sudarsono@yahoo.co.id

\begin{abstract}
Abstrak
Tujuan dari penelitian ini adalah: pertama, mengidentifikasi dan menganalisis secara mendalam nilai-nilai kearifan lokal melalui pendidikan masyarakat (learning society) pascakonflik sosial di Ternate, serta kedua, upaya merevitalisasi nilai-nilai tersebut untuk ditingkatkan dari kearifan lokal menjadi kearifan global. Metode penelitian yang digunakan adalah kualitatif dengan pendekatan postpositivisme phenomenology Interpretif.Tempat penelitian difokuskan pada empat kecamatan yang berada di kota Ternate. Hasil penelitian menunjukkan bahwa, (1) pengembangan nilai-nilai kearifan lokal yang direvitalisasi, melalui: (a) konsensus bersama;(b) reinternalisasi dengan jalur informal, learning society, dan formal.(c) nilai kearifan lokal terdiri dari nilai filosofi, pendidikan, sosial kemasyarakatan, ritual keagamaan, dan nilai kebangsaan. (2) Ternate ikon pluralisme sebagai bentuk kesadaran masyarakat untuk harmoni sosial, yaitu: (a) ketika konflik dan berakhirnya konflik kepercayaan masyarakat menurun, (b) ada subkultur etnis Tionghoa yang merupakan enclave dalam masyarakat Ternate, tetapi harmoni karena ada peran mutualisme, (c) upaya masyarakat yang difasilitasi pemerintah dengan menghimpun berbagai etnis dalam paguyuban dan Forum Pembauran Kebangsaan (FPK) sebagai salah satu upaya untuk mempermudah koordinasi, dan bagi tokoh panutan berada dalam Forum Kerukunan antarUmat Beragama (FKUB). (3) pentingnya Revitalisasi nilai pascakonflik sosial, dapat dilihat dari beberapa faktor, yaitu: (a) tingkat kepercayaan antarumat beragama rendah, (b) tingginya primordial dan fanatisme etnis. (c). tahapan revitalisasi meliputi, transformasi budaya, komunikasi, adaptasi, dan organisasi.
\end{abstract}

Kata kunci: revitalisasi, kearifan lokal, konflik sosial

\section{POST SOCIAL CONFLICT REVITALIZATION OF UNITY IN DIVERSITY VALUES AND LEARNING SOCIETY BASED LOCAL WISDOM IN TERNATE}

\author{
Umar M. Sadjim $^{1}$, Noeng Muhadjir ${ }^{2}$, FX.Sudarsono ${ }^{3}$ \\ Muhammadiyah University of North Moluccas ${ }^{1}$, Yogyakarta state University ${ }^{2,3}$ \\ gupojosa@yahoo.co.id; Sudarsono@yahoo.co.id
}

\begin{abstract}
The aim of this study was: Firts, identify and analyze in depth the values of local wisdom through public education (learning society) after the social conflict in Ternate, and Second, efforts to revitalize these values to be upgraded from local knowledge into global wisdom. The method used is qualitative with phenomenology postpositivisme approach Interpretif.Tempat research focused on four districts in the city of Ternate. The Results of this research are: (1) development of the value of unity in diversity and local wisdom are revitalized, through: (a) consensus; (b) reinternalization with informal channels, learning society, and formal channels, and (c) the value of local wisdom consists of philosophy, educational, social, religious rituals, and nationality. (2) Ternate icon of pluralism as a form of public awareness for social harmony, namely: (a) when the conflict and the end of the conflict decreased public confidence, (b) there is a subculture of Chinese ethnic enclaves within Ternate society, but in harmony because there is the role of mutualism, (c) a community effort facilitated by the government collects in the community and the various ethnic intermingling of the National Forum (FPK) as part of efforts to facilitate coordination, and for being a role model in internal Harmony Forum (FKUB). (3) The importance of post-conflict revitalization of social values can be seen from several factors, namely: (a) the level of trust between religious communities are low, (b) high primordial and ethnic fanaticism, and (c) the stage of revitalization includes cultural transformation, communication, adaptation, and organization.
\end{abstract}

Keywords: revitalization, local wisdom, learning society, social conflicts. 


\section{PENDAHULUAN}

Secara historis konflik yang terjadi di Indonesia sudah dimulai sejak berdirinya kerajaan-kerajaan Hindu Budha hingga kerajaan Islam, yang melakukan ekspansi perluasan wilayah. Kemudian mengalami perkembangannya yang pesat pada masa kolonialisme atau penjajahan. Munculnya konflik sosial disertai dengan kekerasan yang lebih pesat di Indonesia khususnya di daerah-daerah pada masa akhir orde baru, akibat dari mulai melemahnya kontrol negara terhadap masyarakat. Makna kontrol dalam hal ini dapat meliputi berbagai bidang seperti bidang ekonomi yaitu kesejahteraan dan pemerataan, serta sosial budaya, dan kemerdekaan dalam berdemokrasi.

Salah satu analisis bahwa pembangunan di akhir era orde baru banyak yang tidak tepat sasaran dan menyimpan banyak permasalahan di masing-masing daerah. Beberapa daerah di Indonesia yang sebelumnya memiliki stabilitas sosial budaya, dengan kehidupan yang harmoni mulai mengalami ketegangan dan kerisauan yang menyebabkan terjadilah konflik sosial. Seperti halnya konflik sosial di daerah Poso Sulawesi Tengah, Maluku di Ambon, serta Maluku Utara di Kao, Tobelo, Malifut yang menyebabkan kurang lebih 5.000 orang meninggal dunia, dan sekitar 500.000 orang menjadi pengungsi meninggalkan rumah mereka (Rozi, 2006, p. 2). Seiring dengan semangat reformasi yang berbarengan dengan proses otonomisasi dan desentralisasi kekuasaan terjadi peningkatan gejala "provinsialisme" yang identik dengan etnisitas. Oleh karenanya muncul semangat egosentrisme, etnosentrisme yang di kemudian hari menimbulkan permasalahan rumit. (Sudrajat, 2014, p.85).

Konflik sebagai satu fenomena sosial hampir selalu melekat pada setiap kelompok masyarakat. Sebagai sumber pemicu konflik yaitu dari berbagai permasalahan-permasalahan dalam masyarakat berupa ketimpangan sosial, pertentangan atau persaingan antarkelompok yang terjadi di masyarakat. Masyarakat Ternate sebagai suatu komunitas masyarakat yang memiliki kemajemukan budaya, dan beragam suku serta agama dan bagian dari wilayah Indonesia yang pernah mengalami konflik sosial. Konflik yang bernuansa agama atau atas nama agama, muncul karena fenomena kehidupan keberagamaan pada hampir setiap daerah sangat merisaukan.

Munculnya pertentangan yang seakan mengekspresikan atas suatu pemahamanan keberagamaan tersebut, dengan kekerasan atas nama agama kepada agama lain. Bahkan kepada aliran agama tertentu yang akan mengancam tatanan sosial masyarakat dan sendi-sendi kehidupan berbangsa dan bernegara. Padahal sebagai warga negara dengan latar belakang kemajemukan etnik, agama dan adat istiadat serta sosial budaya, sama-sama adalah anak negeri yang berada dalam mozaik Negara Kesatuan Republik Indonesia (NKRI).

Disisi lain konflik sosial terjadi karena adanya pemicu lain seperti kepentingan ekonomi. Adanya perebutan lahan atau tempat usaha dari warga masyarakat pendatang dengan penduduk asli, atau adanya kecemburuan atas keberhasilan warga pendatang, yang sangat survive dalam mengembangkan usaha serta berkomitmen tinggi, sementara penduduk asli tidak terlalu sukses dalam usahanya. Inilah yang menyebabkan timbulnya kecemburuan terhadap warga pendatang. Seperti konflik sosial yang terjadi di Ambon, dan konflik yang terjadi di Poso (Suaedy \& Rumadi, 2007, p.22). Pada tataran kondisi konflik tersebut unsur kepentingan atau vested interest menjadi faktor utama.

Berdasarkan hasil penelitian bahwa penyebab konflik sosial yang terjadi di Poso oleh Suaedy \& Rumadi (2007, p.23) karena faktor kepentingan (vested interested) perebutan posisi-posisi sterategis bidang kepegawaian, yang sebelumnya dikuasai oleh warga Nasrani. Kemudian posisi itu lama kelamaan diduduki oleh Islam karena hasil pilkada, sehingga menyebabkan terjadinya persaingan. Dalam hal ini sumber pemicu terjadinya konflik sosial adalah, politik yang memperebutkan kekuasaan yang dibungkus dengan agama. Karena agama sebagai satu ranah yang sangat sensitif dijadikan sebagai sumber konflik.

Padahal semestinya agamalah yang dapat dijadikan sebagai kekuatan atau power dalam penyelesaian berbagai persoalan sosial kemasyarakatan termasuk konflik sosial. Karena tidak ada satu agamapun yang mengajak umatnya untuk saling membunuh atas nama agamanya. Terutama yang hidup dalam kemajemukan di wilayah hukum negara Indonesia. Hal ini sangat terkait dengan tingkat kebe- 
ragamaan masing-masing individu pemeluk agama. Artinya jika tingkat keberagamaan individu tinggi dan luas serta implementasinya benar, maka pasti akan memberikan pencerahan dalam berpikir. Begitu pula dalam sikap dan perilaku, selalu saling menghormati baik terhadap sesama maupun dengan orang lain.

Sebagaimana Tomagola (2006, p.85) menyatakan konflik sosial tersebut tidak dapat dipisahkan dari pengalaman panjang sejarah masa lalu yang terbelah menurut garis agama antara hubungan Kristen dan Islam. Dikembangkan oleh kolonial Belanda sebagai penjajah dengan menyisakan persepsi negatif terhadap kedua belah pihak, baik Islam maupun bagi pemeluk Kristen dan membuat segregasi pemukiman. Menyebabkan kehidupan masyarakat dengan masing-masing kelompoknya menjadikan perbedaan tersebut yang dapat dilihat dari sikap eksklusiv yang ditunjukkan oleh keduanya.

Perubahan sosial akibat konflik sosial menyebabkan nilai-nilai luhur kearifan lokal menjadi retak dan mulai tergerus. Seperti nilai persatuan dan kesatuan, toleransi, saling menghormati, keikhlasan menerima, saling percaya, dan semangat kebersamaan yang selama ini telah diletakkan dasar-dasarnya oleh para leluhur sebagai pedoman dalam hidup dan kehidupan dan menjadi bingkai persatuan dan kesatuan. Kemudian menimbulkan sikap dan perilaku saling curiga, merasa lebih benar, meningkatnya emosional, serta menurunnya rasa kepercayaan antarsesama warga masyarakat dan antarumat beragama di Ternate.

Secara empirik dampak pascakonflik sosial yang terjadi di Indonesia pada umumnya tidak terlalu jauh berbeda dengan negaranegara lain, yang pernah mengalaminya. Di Amerika seperti dikemukakan oleh Mosselson (2011, p.2) bahwa struktur masyarakat terganggu oleh ada kekerasan atau akibat perang yang mengubah tatanan sosial pada masyarakat menjadi pengungsi pindah ke daerah lain. Seakan hilangnya perasaan keselamatan dan keamanan yang diperparah oleh hilangnya kegiatan rutin setiap hari. Berkurangnya orientasi masa depan pendidikan bagi masyarakat. Pada hal masyarakat diharapkan memiliki peran penting dalam melakukan sosialisasi tentang pentingnya rasa aman dan hidup yang harmoni. Idealnya masyarakat memainkan peran kunci dalam menciptakan arti pentingnya identitas budaya.

Berdasarkan hasil penelitian di Jerman oleh Paulson (2011, p.1), bahwa situasi pascakonflik khususnya pada pascaperang dunia ke-II. Ketika itu di negara bagian telah menawarkan contoh positif pendidikan konflik dan kekerasan yang dapat berkontribusi terhadap rekonsiliasi. Sementara itu Jerman masih belum mengikuti dan hanya berpihak kepada kejahatan Nazi secara terbuka dan akhirnya dalam sejarah terbukti masyarakat menyesali sikap dan perilakunya, dari rekonsiliasi yang ditawarkan negara bagian.

Penelitian lainnya tentang dampak pascakonflik sosial yaitu bidang pendidikan dan demokrasi oleh Davies (2011, p.2) dalam "Conflict, Education and Democracy: Learning the Power of Dissent" (konflik, pendidikan dan demokrasi: belajar dari kekuatan perbedaan pendapat). Bahwa konflik sosial, pendidikan, dan demokrasi merupakan suatu segitiga. Pendidikan memiliki peran yang sangat penting untuk memberikan peluang demokrasi, hal mana kunci dari demokrasi adalah kebebasan berbicara, dan berekspresi, semuanya membutuhkan peran pendidikan. Maka pendidikan pascakonflik khususnya tentang demokrasi menjadi penting bagi sebuah proses pembelajaran bagi masyarakat.

Menurut Muhadjir (2006, p.96) Indonesia sebagai negara besar, di bangun dalam tradisi kebhinekaan, tradisi simbiotik mutual yang mengakui kemajemukan etnik, dan tidak ada tradisi yang hendak saling menegasi atau mendominasi etnik lain serta bukan tradisi saling konflik. Politik pemerintahannya dipersatukan dalam "tunggal ika" yang berangkat dari keadilan di daerah, dan dipersatukan secara simbiotik dalam keadilan-keadilan nasional. Namun sesungguhnya untuk mencegah terjadinya berbagai konflik tersebut, maka Trijono (2009, p.52), menyatakan perlu ditopang dengan adanya konsensus nilai secara luas (broad based concencus) yang melibatkan berbagai pihak sehingga mempunyai legitimasi yang kuat terhadap upaya-upaya kesepakatan damai. Memang sangat dirasakan bahwa ada yang tergerus atau melemah dari bangsa ini berupa konsensus bersama dari nilai-nilai ke-bhinneka-an dan ke-tunggal-ikaan, serta nilai-nilai luhur kearifan lokal yang memiliki spirit dan resources kemajemukan tetapi dalam kesatuan yang tidak mendua. 
Revitalisasi menurut Wallace (1958, p.265) dimaknai sebagai: “... As a deliberate, organized, conscious effort by members of a society to construct a more satisfying culture". Revitalisasi sebagai usaha sistematis dan terorganisir, yang dilaksanakan oleh seluruh lapisan masyarakat untuk menyusun kembali suatu bentuk budaya yang baru dan lebih baik.

Ternate sebagai bagian dari wilayah Indonesia, masyarakatnya masih sangat kuat memegang nilai-nilai luhur sosial budaya dalam kehidupan. Terbukti secara empirik dengan falsafah nilai-nilai budayanya seperti dalam pepatah;'adat se atorang ge matoto agama' (adat dan tata perilaku kehidupan itu hakikatnya/bersendikan pada agama). Mewujud pada tata aturan dan perilaku hidup dan kehidupan sebagai suatu kumpulan dari ide, gagasan, norma, dan falsafah atau bahkan nilai-nilai yang telah berurat akar dapat ditemui dalam kehidupan interaksi sosial masyarakat.

Upaya revitalisasi nilai-nilai luhur kearifan lokal dikembangkan dengan melihat beberapa kondisi empirik,yaitu: pertama; bahwa revitalisasi dilakukan karena roh atau spirit nilai-nilai persatuan dan kesatuan sebagaimana juga terlihat sejak dulu secara historis semangat tersebut pada 'Marimoi Ngone Futuru, Masidika Ngone Foruru' telah tergerus dan mulai bergeser sehingga perlu divitalkan kembali agar tetap menjadi modal sosial untuk interaksi insaniah kehidupan yang harmoni masyarakat Ternate; Kedua, spirit nilai-nilai tersebut dapat dijadikan sebagai sarana pewarisan dan pengembangan dalam arti lebih memperkuat nilai-nilai persatuan dan kesatuan khususnya di lingkungan sosial masyarakat; ketiga, sebagai perekat budaya dengan resources kemajemukan etnis, agama yang dimiliki perlu dipertahankan dan dikembangkan; keempat, hilanganya spirit nilai-nilai dalam resources kemajemukan masyarakat dan semakin berkembangnya tradisi kekerasan, serta upaya pemulihan masyarakat dari trauma dan stereotype; kelima, secara sosiologis-historis masyarakat Ternate memiliki tingkat resources kemajemukan yang cukup tinggi termasuk sistem pertalian dalam keluarga, sehingga berpeluang menimbulkan sikap primordial yang eksklusif; $k e-$ enam, dengan revitalisasi diharapkan dapat menumbuh-kembangkan suatu sikap kesadar- an berbudaya (cultural awarness) bagi harmoni kehidupan masyarakat.

Berdasarkan pada kondisi empirik tersebut maka proses dari revitalisasi nilainilai tersebut, melalui enam tahapan yaitu; tahapan penyusunan atau perumusan sistem nilai, mengkomunikasikan nilai, penataan nilai, penyesuain nilai, transformasi nilai, serta rutinisasi dalam hal ini nilai telah menjadi suatu habitus pada diri setiap individu (Wallace, 1958, pp. 270-275).

Untuk mengamati dan menganalisis, serta berusaha mengembangkan pemaknaan nilai-nilai luhur kearifan lokal pascakonflik sosial dari subjek penelitian, maka penelitian ini lebih difokuskan pada peran tokoh panutan melalui learning society dalam lingkungan masyarakat di Ternate. Hasil observasi awal menunjukkan bahwa sebelum terjadinya konflik sosial, interaksi sosial atau interaksi insaniah masyarakat majemuk berjalan secara normal dan selalu mengedepankan asas kebersamaan tanpa memilah berbagai kemajemukan baik etnis, maupun agama apapun dengan selalu mengedepankan nilai-nilai kebersamaan, kegotong royongan, toleransi antarumat beragama warga masyarakat yang harmoni.

\section{METODE PENELITIAN}

Penelitian ini merupakan penelitian kualitatif, dengan pendekatan yang digunakan adalah postpositivisme phenomenology interpretif. Waktu pelaksanaan penelitian dari bulan september 2014-Agustus 2015. Dilaksanakan pada empat kecamatan dalam wilayah kota Ternate, yaitu Ternate selatan, Ternate tengah, Ternate utara, dan Pulau Ternate. Alasan penetapan lokasi penelitian ini adalah: (1) terjadi penyebaran penduduk di kota Ternate yang tersegregasi lebih dominan berdasarkan suku dan agama di Ternate selatan, sedangkan Ternate utara segregasi berdasarkan agama dengan masing-masing klaster masyarakat; (2) bahwa, kecamatan ini Ternate selatan dan Ternate utara, dan pulau merupakan kecamatan induk yang sudah ada sebelumnya. Dibandingkan dengan kecamatan lainnya. Sedangkan kecamatan Ternate tengah merupakan kecamatan dibentuk dari beberapa kelurahan Ternate selatan dan Ternate utara sebagai daerah yang dimekarkan pascakonflik sosial di Ternate yang secara administratif pemerintahannya telah berjalan secara efektif; 
(3) Kecamatan Ternate selatan dan kecamatan Ternate utara merupakan dua kecamatan yang secara empirik bersentuhan langsung sebagai daerah yang berkonflik di Ternate.

Pengambilan subjek penelitian berdasarkan pilihan secara purposive dengan membagi tokoh panutan dalam kluster-kluster. Yaitu kluster guru, pekerja media, tokoh masyarakat, tokoh agama, dan kluster tokoh adat yang berada pada masing-masing wilayah.

Prosedur penelitian ini adalah sebagai berikut. Pertama, menentukan lokasi; penentuan lokasi penelitian, yang didasarkan pada karakteristik masing-masing kecamatan yaitu kecamatan Ternate selatan dan Ternate utara, kecamatan Ternate tengah dan kecamatan pulau Ternate. Kedua.Mendapatkan akses dan menjalin hubungan; melakukan akses atau hubungan pendekatan dengan subjek penelitian.Tokoh panutan di wilayah kecamatan dengan menunjukkan kluster masyarakat yang dipilih oleh peneliti; Ketiga.Pemilihan dan pengambilan subjek penelitian; melakukan pendekatan lanjutan dengan subjek penelitian. yaitu pada masing-masing kluster pekerja media; kluster guru; kluster tokoh masyarakat, kluster tokoh adat, dan kluster tokoh agama dengan teknik yang telah ditetapkan. Keempat. Pengumpulan data; Pada tahapan ini datadata penelitian mulai dikumpulkan oleh peneliti, untuk diklarifikasi dan di pilah sesuai dengan tema yang telah ditetapkan peneliti, serta tujuan penelitian. Kelima,Pencatatan informasi; kegiatan perekaman informasi kepada subjek penelitian, yang dilakukan bersamaan dengan langkah sebelumnya. Ke-enam, penyelesaian masalah dilapangan berupa kasuskasus negatif yang ditemukan di lapangan. Dilakukan peran kolaborasi berupa diskusi dengan teman sejawat, member check, richeck, dan cross-check dalam triangulasi data yaitu metode dan waktu serta teori. Ketujuh, Penyimpanan data; sebagai kegiatan akhir dari siklus ini adalah berupa penyimpanan datadata penelitian yang diperoleh dari lokasi penelitian. Karena data sewaktu-waktu akan diperlukan dalam pengolahannya. Baik berupa data yang dikumpulkan melalui observasi, wawancara, maupun dokumentasi dari masing-masing kluster. (Creswell, 2007, p. 118).

Teknik pengumpulan data yang dilakukan adalah dengan cara wawancara, observasi partisipatif yang dilakukan untuk menguji sejauhmana kevalidan hasil wawan- cara yang telah di sampaikan oleh subjek penelitian. kemudian dengan data dokumentasi. Untuk analisis data menggunakan teknik induktif phenomenologi oleh Moustakas (1994, p.21) dengan mengikuti tahapan sebagai berikut: (a). pencatatan dan pengelompokkan awal; (b). pengurangan dan penghapusan atas data agar sesuai dengan tema; (c).pengelompokkan unsur-unsur tema yang berbeda; (d).identifikasi akhir dari unsur dan tema yang berbeda; (e). deskripsi tekstural, tentang apa yang dialami individu; (f). Deskripsi struktural, tentang bagaimana individu mengalaminya, dan $(\mathrm{g})$. deskripsi gabungan tektural dan struktural untuk menangkap esensinya.

\section{HASIL PENELITIAN DAN PEMBAHASAN}

\section{Kondisi Kehidupan Pascakonflik sosial}

Suasana kehidupan sangat jauh berbeda ketika pascakonflik sosial atau berakhirnya konflik sosial di Ternate. Pada tahap awalnya memang sangat dirasakan ada hubungan atau relasi sosial yang retak. Seolah-olah ada hal yang sangat krusial atau rumit untuk dibangun. Yaitu membangun kepercayaan antarsesama umat beragama di kota Ternate.

Tidak hanya pada masing-masing umat beragama, para tokoh agamapun masih terdapat saling curiga diantara mereka. Sebab itulah maka kemudian kegiatan-kegiatan di pascakonflik sosial tersebut sangat intensif dan proaktif untuk dilakukan. Secara terus menerus oleh berbagai pihak dan kalangan, selain membangun kepercayaan juga berusaha untuk membangun persepsi warga masyarakat tentang rasa aman untuk hidup di kota Ternate.

Sebagaimana pula dijelaskan secara gamblang oleh ARM (tokoh agama Islamketua Forum Kerukunan antarUmat Beragama (FKUB) kotaTernate dan akademisi). Forum ini di rasakan sangat berperan dalam keberadaannya dalam membantu usaha-usaha pemulihan. Serta menjalin kembali komunikasi insaniah dan relasi sosial antarumat beragama di Ternate.

Secara internal para tokoh agama mendeteksi berbagai persoalan yang muncul. Pertama adalah tingkat kepercayaan, antarumat beragama menjadi sesuatu yang sangat lemah atau tipis. Sehingga para tokoh itu dulu harus meyakinkan sesama tokoh menumbuh- 
kan rasa kepercayaan. Umat yang beragama harus bersatu untuk melawan umat yang tidak beragama. Jadi umat beragama itu harus bersatu. Karena ada prinsip-prinsip keagamaan itu menuju Tuhan. Persoalan Tuhan itu dipersepsi dalam prinsip hidup yang berbeda, tetapi yang dituju adalah Tuhan juga. Kemudian ada yang salah persepsi lalu tidak sampai maka itu persoalan kemanusiaan. Tuhan itu tidak bisa dipersepsi, tetapi kita meyakini bahwa Tuhan itu Maha kuasa, dan Maha menguasai. Kedua, ada prinsip keadilan, kita mengajak pemerintah untuk memberikan kesempatan yang sama pada semua kelompok sesuai dengan kapabilitas, prestasi dan tidak boleh hanya mengambil kelompok tertentu saja. Jadi ada prinsip keadilan, sosial budaya; Ketiga, perlu membangun rasa aman. Artinya tidak merasa adanya keterancaman, sehingga persepsi ini harus dibangun, bahwa anda hidup di sini (Ternate) itu sudah aman. Dan ini Walikota berbicara melalui Media bahwa anda hidup di Ternate itu sekarang sudah aman. (W/18/10/14/ARM).

Berdasarkan analisis koherensi, maka HIM (tokoh agama Islam-Mantan ketua MUI kota Ternate), memberikan pemaknaan baru tentang pengakuan akan keberadaan suatu agama dan kelompok atau umatnya. Bahwa dalam Islam, ada kalimat: 'Lakum diinukum walyadiin'artinya: bagimu agamamu bagiku agamaku, hal ini substansinya adalah mengakui eksistensi agama lain. Kalau mengakui adanya agama yang lain, hal ini berarti bahwa ada pula pemeluknya. Coba lihat saja di bumi inipun bukan hanya ada salah satu umat saja, tetapi masih ada agama-agama yang lain dan itu tetap diberikan ruang untuk berkembang. Sehingga dengan adanya umat dan agama yang lain itu, dengan demikian diperlukan adanya relasi sosial, dan jika ada relasi maka diperlukan adanya komunikasi antarwarga masyarakat dan pemeluk setiap agama. (W/07/01/15/HIM).

Dengan demikian pandangan atau persepsi tentang konflik sosial yang telah dikemukakan oleh informan, bahwa konflik sosial yang terjadi tidak terlepas dari pada pengaruh faktor kepentingan yang sangat besar, serta imbas dari konflik sosial yang terjadi sebelumnya di Ambon. Hal itu karena secara geografis Ternate dan Maluku utara pada umumnya sebagai bagian yang tak terpisahkan. Selain itu kondisi secara nasional memberikan ruang untuk pengelolaan daerah dengan adanya otonomi. Semakin memperkuat faktor kepentingan secara individu untuk kemudian berusaha mencari posisi dan simpatisan kepada warga masyarakat.

Kondisi tersebut jika dilihat dari kerangka teori konflik yang dikembangkan oleh Dahrendorf (1958, p.171) yang mengkategorikan bahwa konflik itu terdiri atas tiga kategori yaitu konflik Individu, konflik konstitusional antarkomunitas dan konflik sistemik. Untuk menjelaskan tentang konflik sosial yang pernah terjadi baik secara nasional maupun secara lokal termasuk di Ternate, maka ada benang merahnya atau hubungan yang sangat kuat yang mengindikasikannya. Bahwa konflik-konflik sosial yang pernah terjadi jauh sebelumnya, di masa silam hingga saat ini lebih khusus konflik di Indonesia, berawal dari konflik-konflik individu dengan sejumlah kepentingan, dan bukan karena konflik agama.Tetapi yang terjadi adalah agama sering dijadikan sebagai pemicu konflik sosial termasuk konflik yang terjadi di Ternate.

Namun demikian, akhir-akhir ini yang sangat dikhawatirkan oleh seluruh komponen warga masyarakat adalah konflik Internal. Konflik yang terjadi pada setiap agama, seperti halnya konflik-konflik internal yang juga sering terjadi di Ternate yaitu tawuran antarkampung (tarkam). Konflik ini dipicu oleh adanya persoalan sepele antara dua individu yang akhirnya melibatkan komunitas antarwarga masyarakat sesama yang beragama Islam. Hal ini ditunjukkan pula dengan tingkat primordial atau rasa homogenitas yang sangat tinggi serta fanatisme kampung yang berlebihan sehingga menyebabkan konflik itu merembes kepada konflik sosial dengan melibatkan warga masyarakat antarkampung atau kelurahan.

Kondisi ini sangat berbeda dengan konflik internal yang pernah terjadi antara warga masyarakat sesama agama Kristen Protestan tetapi berbeda sekte. Agama Kristen Protestan sekte Gereja Protestan Maluku dan Sekte Gereja Injili Halmahera. Konflik ini dipicu oleh adanya perebutan wilayah kegerejaan dari keduanya di wilayah kota Ternate yaitu di kecamatan Kepulauan Batang Dua. Memang jika dicermati secara historisadministratif, wilayah Maluku Utara termasuk Ternate pernah berada dalam wilayah provinsi Maluku yang berkedudukan di Ambon. 
Untuk konflik internal agama dengan mengangkat dua contoh empiris tersebut, baik dalam tubuh agama Islam maupun agama Kristen Protestan, sangat membutuhkan peran serta tokoh agama masing-masing, maupun tokoh adat dan pemimpin informal lainnya dalam melakukan pencerahan, kepada warga masyarakat. Peran mediasi pemerintah mulai dari pemerintah desa, kemudian kecamatan sampai pemerintah daerah. Sehingga sedapat mungkin dapat diatasi benih-benih sumber api konflik internal yang akan memperlemah harmoni sosial warga masyarakat Ternate dalam kemajemukan.

Harmonisasi diperlukan karena memberikan peluang atau kesempatan yang sebesar-besarnya kepada seluruh warga masyarakat untuk menjalani kehidupan yang lebih baik di masa depan. Dalam hal ini, berbagai latar belakang yang dimiliki, baik agama, suku atau etnis, maupun adat istiadat dan sejumlah perbedaan lainnya. Hal lain tidak dilupakan atau diabaikan pula kondisi berdasarkan sosio kultural setiap wilayah dan etnis yang telah memilih Ternate sebagai tempat domisili.

Karakteristik konflik sosial yang bermula dari konflik individu sebagaimana yang dikembangkan oleh Dahrendorf di atas. Jika dikaitkan dengan data hasil penelitian sebagaimana yang diuraikan dalam bagian sebelumnya yaitu pada deskripsi sosio budaya dalam kemajemukan mata pencaharian berdasarkan suku atau etnis. Hal yang terpenting, adanya kemajemukan masyarakat, sebagaimana dalam konsep Bhinneka Tunggal Ika, bahwa preferensi dari pluralisme budaya yaitu budaya mayoritas atau budaya induk dan oleh budaya minoritas selalu mengikutinya. Namun yang terjadi di Ternate, yaitu dengan adanya etnis Tionghoa yang secara subkultur budaya masyarakat sejak awal, diakui keberadaannya secara enclave dan terjadi harmoni sosial. Karena warga masyarakat Tionghoa sejak awala telah memiliki peran yang sangat penting sebagai pengembang dan pemegang otoritas ekonomi perdagangan serta bidang sosial.

\section{Identifikasi Nilai-nilai Kearifan Lokal dan Nilai Bhinneka Tunggal Ika di Ternate}

Tahapan Penjaringan (koleksi) atas Nilai-Nilai Kearifan Lokal
Kearifan lokal yang dimaknai oleh masyarakat sebagai suatu pengetahuan, nilainilai yang terseleksi dalam suatu kelompok masyarakat dan yang masih dipegang teguh. Dalam konteks masyarakat Ternate nilai-nilai tersebut dapat di implementasikan untuk membentuk tatanan kehidupan masyarakat yang heterogenitas dan harmoni dengan memiliki jiwa yang kuat, rasa hormat menghormati sesama dan saling percaya untuk kemajuan bersama. Kemudian berdasarkan hasil observasi pula bahwa kearifan lokal masyarakat Ternate sangat banyak.

Tahapan Penyaringan (seleksi) Nilai-Nilai Kearifan Lokal.

Tahapan penyaringan atau seleksi atas masing-masing nilai kearifan lokal tersebut, dimaksudkan untuk melihat atau mendeskripsikan nilai-nilai kearifan lokal yang masih perlu untuk dipertahankan dan yang sudah tergerus oleh perkembangan zaman. Berdasarkan koleksi nilai-nilai kearifan lokal tersebut, maka selanjutnya akan diuraikan nilai kearifan lokal apa saja yang terseleksi atau mulai melemah pascakonflik sosial di Ternate.

Nilai-nilai kearifan lokal yang telah melemah tersebut dalam pengejawantahannya, sangat diperlukan adanya komitmen dan konsensus secara bersama-sama dari semua pihak. Terutama lembaga kesultanan dan perangkatnya, serta para cendekiawan, dan ulama atau tokoh-tokoh agama. Untuk kemudian melakukan pembahasan termasuk dari pihak pemerintah daerah yang memfasilitasinya. Menyeleksi nilai-nilai dan bentuk adat istiadat yang dimiliki oleh leluhur selama ini dengan menggunakan formula yang sesuai, termasuk formula agama. Terutama yang berhubungan dengan nilai-nilai universal seperti hormat menghormati, keadilan, dan kejujuran, serta sikap menghargai perbedaan. Dengan demikian nilai-nilai budaya apapun yang dikembangkan asal masih ditolerir oleh aturan-aturan agama, hal itu akan diikuti dan diaplikasikan pula oleh seluruh warga masyarakat Ternate tanpa kecuali.

Sebagaimana pendapat Kuntowijoyo (1991, pp.385-389) bahwa, dalam konteks budaya termasuk nilai-nilai budayanya Indonesia pernah mengalami dua bentuk budaya. Dua budaya itu yakni budaya keraton yang diiden- 
tikkan dengan penuh mitos dan mistik kemudian ada pengaruh kebudayaan Islam setelah masuknya Islam. Selanjutnya kedua adalah budaya populer yang mewakili budaya warga masyarakat atau budaya rakyat di luar keraton yang bersikap sangat terbuka, untuk menerima kebudayaan Islam. Jika mengacu kepada kedua bentuk budaya tersebut walaupun dalam pembahasannya lebih mengarah kepada kasuistik di jawa. Namun ada benang merahnya dengan kondisi empirik secara historis, ekspresi budaya di Ternate yang memiliki unsur kemiripan atas kedua bentuk budaya itu.

Tabel 1. Penjaringan Nilai-Nilai Kearifan Lokal di Ternate

\begin{tabular}{|c|c|c|}
\hline \multicolumn{3}{|c|}{ Nilai-nilai kearifan lokal di Ternate } \\
\hline Nilai Vertikal & Nilai Horisontal & Yang terseleksi \\
\hline $\begin{array}{l}\text { Kololi kie (keliling } \\
\text { pulau Ternate) }\end{array}$ & $\begin{array}{l}\text { Bobaso se rasai } \\
\text { (taat, cinta dan } \\
\text { kasih sayang) }\end{array}$ & $\begin{array}{l}\text { Bobaso se rasai } \\
\text { (cinta dan kasih } \\
\text { sayang) }\end{array}$ \\
\hline $\begin{array}{l}\text { Juo se ngofa ngare } \\
\text { (Tuhan dan hamba) }\end{array}$ & $\begin{array}{l}\text { Makugawene } \\
\text { (kasih sayang) }\end{array}$ & $\begin{array}{l}\text { Makugawene } \\
\text { (kasih sayang) }\end{array}$ \\
\hline $\begin{array}{l}\text { Joko kaha (injak } \\
\text { tanah) }\end{array}$ & $\begin{array}{l}\text { Liliyan (kerja sama } \\
\text { kaum ibu). }\end{array}$ & $\begin{array}{l}\text { Jou sengofa ngare } \\
\text { (Tuhan dan } \\
\text { hamba) }\end{array}$ \\
\hline $\begin{array}{l}\text { Gogoro,butu } \\
\text { (undangan) }\end{array}$ & Jojobo (menabung) & $\begin{array}{l}\text { Jojobo,Gogoro } \\
\text { (undangan,mena } \\
\text { bung). }\end{array}$ \\
\hline $\begin{array}{l}\text { Boso Ici (doa tolak } \\
\text { bala) }\end{array}$ & $\begin{array}{l}\text { Oro gia, babari } \\
\text { (gotong-royong) }\end{array}$ & $\begin{array}{l}\text { Oro gia, babari } \\
\text { (gotong-royong) }\end{array}$ \\
\hline $\begin{array}{l}\text { Dolo bololo, dalil } \\
\text { tifa se dalil moro } \\
\text { (pesan agama dan } \\
\text { sosial, budaya) }\end{array}$ & $\begin{array}{l}\text { Nita Malili } \\
\text { (menjemput fajar, } \\
\text { berpagi-pagi dalam } \\
\text { kerja) }\end{array}$ & $\begin{array}{l}\text { Dolo bololo, Nita } \\
\text { malili (pesan } \\
\text { agama, berpagi- } \\
\text { pagi kerja) }\end{array}$ \\
\hline $\begin{array}{l}\text { Tagi-tagi, tego se } \\
\text { hotu mai sabea } \\
\text { (selalu ingat Tuhan). }\end{array}$ & $\begin{array}{l}\text { Bari fola (kerja } \\
\text { sama membangun } \\
\text { rumah). }\end{array}$ & $\begin{array}{l}\text { Bari fola, dodara } \\
\text { ngofa (bangun } \\
\text { rumah, sayang } \\
\text { anak) }\end{array}$ \\
\hline $\begin{array}{l}\text { Fere buku (naik } \\
\text { gunung gamalama). }\end{array}$ & $\begin{array}{l}\text { Dodara Ngofa } \\
\text { (sayang anak). }\end{array}$ & $\begin{array}{l}\text { Jou kasa ngom } \\
\text { kage, Legugam } \\
\text { (loyalitas, festival } \\
\text { budaya). }\end{array}$ \\
\hline $\begin{array}{l}\text { Jou Kasa Ngom } \\
\text { Kangee } \\
\text { (kepatuhan/loyalitas) }\end{array}$ & $\begin{array}{l}\text { Legu Gam (festival } \\
\text { budaya) }\end{array}$ & \\
\hline
\end{tabular}

Secara umum budaya di Ternate, dapat digolongkan kepada kedua kebudayaan ini yaitu kebudayaan keraton dan kebudayaan populer dari rakyat di luar keraton kesultanan. Keduanya dapat digolongkan sebagai kebudayaan tradisional. Kebudayaan internal yang dimaksudkan yaitu yang berhubungan dengan cara pandang maupun perilaku keseharian yang berlaku di kesultanan. Bentuk kebudayaan ini dikembangkan oleh para pegawai istana kesultanan, termasuk para pujangga dan arsiteknya.

Sedangkan posisi keberadaan raja atau sultan memiliki kepentingan untuk menciptakan berupa simbol-simbol, atau tanda budaya tertentu dalam rangka untuk memperkuat posisi dan kedudukannya. Simbol-simbol itu seperti mitos, sastera kerajaan dan hikayathikayat, cerita-cerita ajaib, dan kesaktian raja. Hal ini dilakukan untuk memperoleh dukungan rakyat dan memiliki loyalitas atas kepemimpinan raja atau sultan. Misalnya di Ternate mengenal adanya kualitas supra-insaniah raja atau sultan. Yaitu sultan dianggap memiliki kemampuan untuk memosisikan diri sebagai manusia dan pada kondisi tertentu sebagai kolano ketika berada ditempat tertentu. Ketika pada posisi supra-insaniah maka pembicaraannya disamakan dengan Tuhan. Untuk memutuskan suatu bentuk perkara atau kasuistik di lingkungan keraton kesultanan.

Selain mitos sebagaimana yang telah diuraikan, juga dikenal adanya penciptaan atas sastera mistis. Jika mitos tersebut diperuntukkan dalam rangka mengukuhkan kekuasaan raja termasuk loyalitas pegawai istana kepada raja, maka lain halnya dengan mistis sebagai salah satu upaya untuk memberikan pengetahuan-pengetahuan dasar tentang kosmologi. Misalnya dalam khasanah mistis di Ternate dikenal adanya konsep tentang "toma ua hang moju, koa i dadi sosira" (disuatu tempat yang belum ada apa yang lebih dulu ada), merupakan suatu konsep yang mengajarkan tentang realitas kosmos dan kedudukan manusia di dalamnya. Contoh sastera mistik seperti ini mengindikasikan dan secara implisit memberikan pesan agar pegawai istana dan manusia pada umumnya berusaha untuk mampu memahami diri dan dunianya dalam konteks kosmologi keraton.

Sebagai upaya memperkuat kedudukan dan kekuasaan raja atau sultan. Kemudian menciptakan silsilah genealogis sebagai keturunan dari dewa atau kayangan. Tetapi dapat pula memosisikan diri berasal dari keturunan Nabi atau para sahabat Nabi. Dengan demikian dapat dikatakan bahwa pada konteks ini ternyata tidak terlepas dari pada pengaruhpengaruh dari filsafat sosial Hindu bahkan pra-Hindu. Kemudian setelah datangnya 
kebudayaan Islam seperti mistesisme Islam berpengauh pula dalam pemahaman-pemahaman internal keraton. Artinya dengan kebudayaan Islam untuk selanjutnya digunakan untuk melegitimasi atau memperkuat pemahaman dan pandangan dilingkungan internal keraton.

Satu sikap yang patut di berikan perhatian dan diapresiasi secara penuh bahwa setelah datangnya Islam secara institusi dan kebudayaan-kebudayaannya. Ternyata dari pihak pengembang kebudayaan internal keraton yang digolongkan sebagai kebudayaan tradisional lebih memilih untuk menerima dan menyesuaikannya dengan adat istiadat serta budaya keraton. Sikap ini sekaligus memberikan suatu karakteristik dari kebudayaan internal keraton yang lebih fleksibel, dalam menerima suatu bentuk budaya serta nilai-nilai yang mendukung budayanya. Termasuk dalam hal melegitimasi atas nilai-nilai budaya tradisonal yang kemudian dikenal dengan nilai-nilai luhur kearifan lokal. Sebagai suatu kumpulan nilai-nilai yang masih diyakini oleh masyarakat, dapat dijadikan sebagai power atau pendorong dan pendukung semangat hidup dan kehidupan warga masyarakat untuk mencapai kesuksesan masa depan.

Bentuk kebudayaan yang kedua yaitu kebudayaan eksternal merupakan budaya warga masyarakat atau budaya rakyat yang berada di luar keraton kesultanan. Tidak terlalu jauh berbeda dengan budaya internal keraton kesultanan, pada budaya rakyat ini dikenal pula adanya cerita-cerita mitologi dan semacamnya. Misalnya pada masa adanya bajak laut atau perompak di daerah Maluku Utara dan sekitarnya. Mengenal adanya para perompak yang bisa menghilang. Atau ada guru mengaji atau khalifah yang bisa shalat di tempat lain tanpa menggunakan perantara, kemudian balik lagi ke tempat semula.

Beberapa contoh tersebut menunjukan bukti empirik dari pada budaya eksternal atau budaya rakyat dan warga masyarakat di luar keraton kesultanan. Namun di sisi lain ekspresi-ekspresi ritual dalam budaya rakyat, termasuk seni musik juga menunjukkan pengaruh budaya Islam yang sangat kuat, yang terproses dalam keseluruhan sikap dan perilaku warga masyarakat. Misalnya upacara sosial budaya dalam "arwahang" masih hidup hingga saat ini sampai di daerah pelosok desa, sebagai salah satu bentuk kegiatan untuk memperingati Maulid kelahiran nabi. Begitu pula dalam bidang seni musik sangat terlihat nuansa pengaruh kebudayaan Islam seperti qasidah dengan menggunakan alat pukul berupa rebana, begitu pula gambus dengan diiringi syair-syair yang mengandung nilainilai tentang nasehat kehidupan, keagamaan dan tatakrama serta perilaku positif lainnya.

Kemudian mengacu pula pada kajian teori, tentang pendekatan teori pluralisme budaya yang dikembangkan dari Bhinneka Tunggal Ika oleh Muhadjir (2013, p.13), bahwa dalam pemaknaan baru Bhinneka Tunggal Ika tidak hanya dilihat dari konteks agama yang berbeda, tetapi mayoritas menghargai dan melindungi yang minoritas. Jika ada penyimpangan dalam prakteknya yang dilakukan oleh mayoritas, maka wajib kepada minoritas untuk memberikan masukan dan pencerahan-pencerahan.

Masyarakat Ternate secara historis yang mula-mula disebut sebagai Ternate awal, merupakan masyarakat yang berbudaya secara monokultur dan homogen. Keberadaan mereka di lereng gunung gamalama, dengan mata pencaharian pokok bertani dan berkebun. Menanam cengkih dan pala serta kelapa, sesekali turun ke daerah pantai untuk menangkap ikan yang dikonsumsi sendiri. Kondisi itu sangat mengalami perubahan yang sangat positif, ketika mulai berdatangannya warga pendatang (Malayu Cim) ke Ternate dan mulai berinteraksi dari dua kelompok masyarakat. Pada akhirnya terjadi suatu bentuk budaya baru yang selanjutnya disebut dengan budaya multikultur. Sebagai salah satu bentuk dari hasil interaksi tersebut maka adanya pengakuan akan keragaman budaya dan adat istiadat, serta mengakui keunggulan nilai-nilai budayanya masing-masing.

Upaya yang bersifat metamotif sukses diperlukan yaitu suatu usaha yang berkelanjutan dan selalu memiliki progress positif dan berkembang secara terus menerus dari berbagai kecakapan yang dimiliki seperti kecakapan intelektual, sosial, emosional dan kecakapan religius Kuhlen, (dalam Muhadjir, 2014, p.64). Untuk menjadikan nilai-nilai budaya dan kearifan lokal Ternate, lebih memiliki nilai tambah (Value added) bagi pengembangan warga masyarakat Ternate dengan pluralisme budayanya. Sekaligus sebagai refleksi atau cerminan diri dalam menghargai nilai kearifan lokal. 


\section{Pengembangan Nilai-nilai Bhinneka Tunggal Ika dan Kearifan Lokal Melalui Learning Society}

\section{Re-Internalisasi Nilai-Nilai Kearifan Lokal dalam Kehidupan di Ternate}

Berdasarkan faktor sosio budaya yang turut mempengaruhi internalisasi nilai-nilai kearifan lokal. Maka internalisasi nilai tersebut melalui cara berikut: (1). melalui jalur informal; melalui keluarga, begitu pula kegiatan keagamaan di mesjid atau di gereja; (2). melalui jalur formal; yaitu sekolah, dan instansi pemerintah, dan (3). Jalur non-formal;. Melalui organisasi kemasyarakatan, Forum kerukunan dan paguyuban. Ketiga cara atau jalur ini akan berkontribusi dalam reinternalisasi secara bersama dan dinamis nilainilai kearifan lokal di Ternate.

\section{Peran Tokoh Panutan: Pemaknaan Learning Society}

Tokoh panutan dalam konteks budaya masyarakat Ternate memiliki pengaruh dan peran besar dalam proses pembentukan kepribadian masyarakat. Tercermin dalam sikap dan perilaku secara individu atau kelompok. Pengaruh besar yang dimaksudkan adalah karena dihormati, memiliki jabatan atau status informal termasuk karena keturunannya. Sedangkan perannya yang besar adalah kemampuan dan kecerdasan dalam mempengaruhi seseorang atau sekelompok orang, memiliki sifat empati, integritas dan kredibilitas.

Dalam kontek Learning society, tokoh panutan memiliki peran dalam memberikan pencerahan kepada warga masyarakat. Mereka yang dimaksudkan yakni tokoh agama, tokoh masyarakat, tokoh adat, orang tua dan termasuk guru. Begitu juga dengan pekerja media yang dapat mempengaruhi public opinion. Terutama dalam meliput dan merefleksi serta memaknai suatu fenomena atau peristiwa yang terjadi di dalam suatu kelompok masyarakat menjadi sangat penting adanya.

Untuk selanjutnya diperlukan pula kontrol sosial bagi terimplementasikannya nilai-nilai kearifan lokal tersebut. Pendekatan kontrol sosial yang penting menurut Soemarjan (2002, p. 309) adalah: (1) kontrol sosial secara formal oleh alat negara dalam hal ini pemerintah; (2) kontrol sosial secara non formal dari masyarakat melalui berbagai tokoh panutan yang ada dalam suatu kelompok masyarakat, serta (3) kontrol sosial dari dalam diri pribadi atau inner control. Masingmasing individu sebagai anggota masyarakat senantiasa melakukan pengendalian diri secara internal yaitu mampu untuk menahan emosi, egoisme, pre-judice, menekan sikap dan perilaku yang merugikan kepentingan orang banyak, serta sikap negatif lainnya.

Secara empirik sangat terasa bahwa adanya resolusi konflik atau berakhirnya konflik sosial di Ternate, tidak hanya peran dari kontrol atau pengendalian secara formal. Walaupun ketika terjadinya konflik sosial di Ternate memang peran kontrol formal sangat dibutuhkan. Tetapi dorongan untuk mengakhiri konflik sosial itu sendiri adalah atas inisiatif atau dorongan besar dari warga masyarakat masing-masing pemeluk agama. Adalah tokoh-tokoh agama, adat, masyarakat, ketua RT dan RW, serta masing-masing kepala keluarga, yang disebut sebagai tokoh panutan. Hal ini juga disebabkan karena secara habitus atau kebiasaan warga masyarakat yang secara manusiawi memiliki jiwa kebebasan berekspresi dengan berbagai profesi. Adanya konflik sosial kondisi itu telah berada pada titik treshol yang menyebabkan masyarakat tidak berekspresi. Sehingga model atau bentuk kontrol sosial secara non formal serta kontrol dari dalam sangat determinan dalam mengakhiri konflik sosial. Artinya warga masyarakat seakan mengalami pressure dan stresser secara internal dalam diri dengan adanya konflik, sehingga dorongan kuat dari dalam untuk mengakhiri konflik sosial tersebut.

Kontrol sosial secara simbolik dengan menggunakan simbol-simbol. Berupa tulisan yang berisi pesan-pesan moral untuk menjaga nilai-nilai kearifan lokal di tempat publik, yaitu Bandara udara, kantor pemerintahan, sekolah, bangunan-bangunan kuno. Sebagai icon pluralisme budaya yang memiliki nilainilai historis bagi kepentingan generasi muda untuk pengembangan ilmu pengetahuan.

Nilai-Nilai Kearifan Lokal yang Koheren dengan Nilai Bhinneka Tunggal Ika.

Dapat digolongkan dalam beberapa bidang yaitu: bidang filosofis, sosial kemasyarakatan, ritual keagaman, pendidikan, dan bidang kenegaraan atau kebangsaan. 
Ternate sebagai Icon Pluralisme Pascakonflik sosial: bentuk Kesadaram Masyarakat melalui Sikap dan Perilaku Harmoni Sosial

Secara historis Ternate sejak dulu telah menjalin hubungan dengan bangsa lain. Yaitu dengan bangsa Cina disusul dengan para gujarat dari Arab. Sehingga hubungan masyarakat Ternate awal yang monokultur berproses menjadi masyarakat yang multikultur. Dengan adanya konflik sosial maka tingkat kepercayaan antarwarga masyarakat menurun.

Pascakonflik warga masyarakat mulai menyadari bahwa beta pentingnya hidup secara bersama, yang kemudian mengakhiri konflik tersebut berdasarkan nilai-nilai luhur kearifan lokal, yang difasilitasi pemerintah. Berdasarkan teori pluralisme budaya yang dikembangkan dari Bhinneka Tunggal Ika, bahwa secara preferensi budaya minoritas akan mengikuti budaya mayoritas. Namun yang terjadi di Ternate adalah masih ada subkultur masyarakat Tionghoa yang enclave dalam masyarakat Ternate, tetapi harmoni karena ada peran dalam bidang ekonomi perdagangan dan sosial. Terbukti etnis Tionghoa diberikan gelar kesultanan oleh sultan Ternate sebagai Kapita Cina (pemimpin Cina) di Ternate.

Untuk mendukung Icon pluralisme tersebut di Ternate, ada usaha-usaha warga masyarakat yang difasilitasi pemerintah daerah. Untuk menghimpun berbagai etnis di Ternate dalam wadah paguyuban, dan masingmasing paguyuban memberikan perwakilannya pada Forum Pembauran kebangsaan (FPK). Sedangkan tokoh panutan terhimpun dalam wadah Forum Kerukunan antarUmat Beragama (FKUB). Hal ini dilakukan sebagai salah satu mozaik dalam pembangunan di daerah berbasis nilai-nilai kearifan lokal.

\section{SIMPULAN DAN SARAN}

\section{Simpulan}

Pentingnya revitalisasi nilai-niai melalui tahapan transformasi budaya, komunikasi, adaptasi dan organisasi pascakonflik sosial meliputi: (a) pascakonflik sosial tingkat saling memiliki kepercayaan antarumat beragama, semakin menurun bahkan dapat dikatakan tidak ada, jiwa egoisme meningkat, dan pre-judice atau berprasangka. Untuk mulai meningkatkan rasa kepercayaan itu, maka dimulai dari masing-masing tokoh agama untuk saling memberikan kepercayaan sesama mereka. Setelah itu baru dengan warga masyarakat pada masing-masing agama; (b) semangat primordial dan fanatisme terhadap etnis masih sangat tinggi hingga saat ini. Sementara jiwa dan semangat heterogenitas sangat rendah; (c) dibutuhkan peran-peran tokoh panutan dalam memberikan pencerahan-pencerahan pengetahuan, serta pengalaman dan kontrol sosial. Kontrol sosial yang sangat perlu adalah baik secara formal melalui peran pemerintah, maupun secara non-formal melalui tokoh-tokoh panutan. Dan yang selanjutnya adalah adanya kontrol sosial secara internal atau Inner control. Masing-masing individu warga masyarakat berusaha untuk menahan diri tidak melakukan sikap dan perilaku yang merugikan kepentingan orang banyak. Serta yang terakhir adalah kontrol sosial secara simbolik, yaitu melalui simbol berupa tulisan-tulisan yang berisi pesan-pesan moral yang bersumber dari nilai-nilai kearifan lokal yang telah diletakkan dasar-dasarnya oleh para leluhur bangsa di daerah; (d) tahapan revitalisasi yang dilak-sanakan di Ternate, yang mengacu kepada teori tahapan revitalisasi adalah: (1). transformasi budaya; (2). Komunikasi; (3). adaptasi, dan (4). organisasi. Keempat tahapan revitalisasi tersebut berjalan tidak secara sirkuler/ liniear, tetapi berjalan secara siklus.

Ternate sebagai Icon pluralisme Pascakonflik sosial: bentuk kesadaran masyarakat melalui sikap dan perilaku harmoni sosia adalah sebagai berikut. Pertama, secara historis, bahwa Ternate sejak dulu telah menjalin hubungan dengan bangsa-banga luar. Sebelum datangnya bangsa eropa adalah Cina disusul oleh para gujarat dari Arab yang mengadakan hubungan dengan masyarakat Ternate awal yang monokultur, dan kemudian menjadi Ternate yang multikultur karena menerima bukan saja dari Cina dan Arab tetapi warga lainnya seperti dari Jawa dan Sulawesi yang lebih didominasi oleh hubungan dagang dan berjalan hingga saat ini secara harmoni.

Kedua, ketika konflik sosial tingkat kepercayaan dan toleransi warga masyarakat menurun. Menyebabkan secara psikologis membawa ketidaknyamanan dari masingmasing pihak yang berkonflik, karena putusnya hubungan komunikasi dan tidak bebas dalam melakukan ekspedisi barang dagangan 
antarkecamatan, antarpulau dan bahkan kabupaten. Menyebabkan ekonomi tidak berjalan sebagaimana biasanya; Ketiga, pascakonflik dengan kesadaran warga masyarakat kedua bela pihak dengan konsensus bersama berusaha untuk mengakhiri konflik sosial, difasilitasi pemerintah. Berdasarkan pula pada nilainilai kearifan lokal yang selama ini telah ditanamkan oleh pada leluhur, tanpa melihat latar belakang agama, etnis, dan budaya serta adat istiadatnya. Nilai-nilai pluralisme budaya yang dikembangkan dari seloka Bhinneka Tunggal Ika telah inklude di dalamnya.

Keempat, berdasarkan teori pluralisme budaya yang dikembangkan dari nilai-nilai Bhinneka Tunggal Ika, bahwa adanya preferensi budaya mayoritas terhadap budaya minoritas. Namun yang terjadi di Ternate masih adanya subkultur masyarakat Tionghoa yang enclave dalam masyarakat di Ternate. Hal ini karena adanya hubungan sosial dan ekonomi perdagangan yang terjadi secara mutualisme atau saling menguntungkan dari warga masyarakat Etnis Tionghoa dengan masyarakat Ternate pada umumnya, serta membantu peningkatan pertumbuhan ekonomi di Ternate, sehingga tetap terjadi harmoni sosial. Kelima, ada usaha-usaha warga masyarakat yang difasilitasi pemerintah untuk menghimpun berbagai etnis baik masyarakat lokal maupun masyarakat pendatang, yang telah menjadikan Ternate sebagai bagian dari hidup dan kehidupannya. Untuk para tokoh panutan berhimpun dalam wadah yang disebut dengan Forum Kerukunan antarUmat Beragama (FKUB). Forum ini yang senantiasa melakukan pertemuan secara berkala melalui dialog-dialog masalah keagaman dan sosial kemasyarakatan. Sedangkan untuk masingmasing para pemuda dan warga masyarakat berdasarkan etnis dihimpun dalam wadah masing-masing organisasi Paguyuban. Dan dari organisasi paguyuban itu terhimpun lagi perwakilannya dalam Forum Pembauran Kebangsaan (FPK). Forum ini sangat berhasil di Ternate, dengan melakukan sosialisasi kepada warga masyarakat di Ternate tentang pentingnya menjalin dan menjadi bagian satu dengan yang lainnya sebagai mozaik dalam pembangunan Ternate untuk semua, tanpa melihat berbagai latar belakang masingmasing. Begitu pula melaksanakan kegiatankegiatan sosial kemasyarakatan yaitu bakti sosial lintas sosial budaya, dan agama di Ternate.

\section{Saran}

Pemerintah daerah kota Ternate, dalam penyusunan perencanaan pembangunan daerah kota Ternate dalam hal penataan kota, agar selalu memperhatikan nilai-nilai kearifan lokal sebagai basis pembangunan di daerah. Atau pembangunan berbasis nilia-nilai kearifan lokal. Karena nilai merupakan sesuatu yang abstrak atau yang intangible dan hal itu sangat mengikat dan mempribadi pada diri setiap individu menuju suatu masyarakat terdidik (educated society) sebagai perwujudan dari adanya kesadaran berbudaya (culture awareness).

Melalui Dinas kebudayaan dan Dinas pendidikan, untuk membuat simbol atau tanda terkait dengan bangunan-bangunan yang memiliki nilai-nilai historis dan yang mendukung Icon pluralisme di Ternate. Kemudian mensosialisasikan kepada warga masyarakat untuk ikut serta memanfaat-kannya, merawat, melindungi, sebagai suatu perwujudan dari sikap dan perilaku yang menjunjung tinggi kesadaran berbudaya warga masyarakat.

Pemangku adat kesultanan Ternate, agar terus melakukan sosialisasi atas nilainilai kearifan lokal, serta mengawal perwujudannya dalam lingkungan masyarakat. Bekerja sama dengan seluruh perangkat adat Mahimo Gam atau kepala kelurahan, dan Gam Mahimo atau tokoh adat di masing-masing lingkungan kelurahan atau kampung di kota Ternate.

Warga masyarakat Ternate, agar terus mempertahankan nilai-nilai kearifan lokal serta yang mendukung nilai-nilai Bhinneka Tunggal Ika, untuk hamoni sosial di Ternate. Dengan selalu mengedepankan kepentingan bersama dalam keseluruhan sikap dan perilaku sehari-hari.

\section{DAFTAR PUSTAKA}

Amal, M.A. (2010a). Portugis dan Spanyol di Maluku. Depok: Komunitas Bambu.

Amal, M.A. (2010b). Kepulauan rempahrempah: perjalanan sejarah Maluku utara 1250-1950. Jakarta: Kepustakaan Populer Gramedia.

Creswell, J.W. (2007). Qualitative inquiry \& research design: choosing among five 
approaches. London: Sage Publication.

Dahrendorf, R. (1959). Class and class conflict in industrial society. Calivornia: Stanford University Press.

Davies, L. (2011). Conflict, Education and Democracy: Learning the Power of Dissent. Journal conflict and education, 1-1.

Kuntowijoyo. (1991). Paradigma islam: interpretasi untuk aksi. Bandung: Mizan.

Muhadjir, N. (2013). Psikologi positif dalam konteks multikultural. dalam psikologi positif oleh Muhadjir (Ed). Yogyakarta: Rake Sarasin.

Muhadjir, N. (2000). Ilmu pendidikan dan perubahan sosial:teori pendidikan selaku Sosial kreatif.Yogyakarta: Rake Sarasin.

Muhadjir, N. (2001). Identifikasi faktor-faktor opinion leader inovatif bagi pembangunan masyarakat. Yogyakarta: Rake Sarasin.

Moustakas, C. (1994). Phenomenological research method. London: Sage Publication.

Mosselson, J. (2011). Conflict, Education and Identity. Resettled Youth in the
United States. Journal conflict and education, 1:1.

Soemardjan, S. (2002). Konflik-konflik sosial di Indonesia: Refleksi keresahan masyarakat. Jurnal analisis CSIS.Tahun ke-XXXI,No.3.

Sudrajat, S. (2014). Revitalisasi pendidikan multikultural dalam pembelajaran. Journal Pembangunan Pendidikan Fondasi dan Aplikasi, 2(1). Retrieved fromhttp://journal.uny.ac.id/index.php /jppfa/article/view/2620. Diakses 2511-2015.

Wallace, A.F.C. (1958). The dekanawideh myth analyzed as the record of a revitalization movement. Journal the American society for ethnohistory, Vol. 5, No. 2, pp. 118-130.

Paulson, J. (2011), Conflict, education, and curriculum: contemplating, past, present, and future. Journal Interdisiplinairy, enganged research.United Kingdom bet spaUniversity.

Peraturan Daerah nomor 13, tahun 2009, tentang pengakuan hak-hak masyarakat adat kesultanan Ternate.

Rozi, S. et.al. (2006). Kekerasan komunal: anatomi dan resolusi konflik di Indonesia. Yogyakarta: Pustaka Pelajar. 